realistic and related to the kind of State desired, rather than to particular political doctrines or shortterm Treasury dictates. Here, as in our attitude to the future of voluntary action, we are faced with a challenge to thought. If we really wish to build the good society, to safeguard the institutions which provide the growing-points and starting-points of creative advance in whatever field, we are taken back to this imperative and inescapable duty of re-examining, and where necessary re-shaping, the institutions which at present minister to our needs, so that they serve our purposes more effectively in the conditions of to-day. We need to be clear as to what those purposes are, and we need to be sure, as Prof. Robbins reminds us, that we are not allowing factors under our control, by neglect or default, to carry us further from our goal. Lady Morris's book and Prof. Robbins's notes on public finance have this in common, that they challenge us to such examination and to constructive thought. They can equally remind us of Lord Beveridge's words : "Emphasis on duty rather than assertion of rights presents itself to-day as the condition on which alone humanity can resume the progress in civilization which has been interrupted by two world wars and which remains halted by their consequences". Much has happened in the seven years since Lord Beveridge wrote those words to attest their truth; and if Lady Morris's book may be expected to engage more particularly the attention of professional associations of scientists, Prof. Robbins's article will at least remind them that even fiscal policy can be such as to foster rather than to discourage initiative, enterprise and the free intercourse of minds and exchange of ideas, which are the root of creative activity and the advancement of knowledge in every field.

\section{THE PERSONALITY OF A GENIUS}

\section{Darwin Revalued}

By Sir Arthur Keith. Pp. $x+294+5$ plates. (London: C. A. Watts and Co., Ltd., 1955.) 25s. net.

THE title of this book by the late Sir Arthur 1 Keith is, perhaps, something of a misnomer. $\mathrm{He}$ does not attempt any major revaluation of Darwin's scientific work but, rather, is concerned in the main with Darwin the man, with the events and tempo of his life and his habits of mind and body. Again it is not so much a revaluation of these that we are offered, but rather a condensation of the enormous mass of data which Darwin left behind him in the form of letters and other writings. Fow lives are better documented; the very richness of the sources makes it a laborious task to extract out of them a fair and complete view. Sir Arthur writes: "I have tried as far as possible to make Darwin tell the story of his life in his own words, while I am merely playing the part of a "cinema-operator" ".

I think most readers will agree that this endeavour has been very successful. But what an astonishing and complex character Darwin was, and how difficult to form a just picture of him! Towering above everything else is his majestic grandeur as a scientist and as a thinker who changed the whole of man's view of his position in the universe. But at the same time his weaknesses as a human being are very obvious. He remained a devoted parent, and a kindly and helpful colleague to his scientific contemporaries; but throughout most of his life, his devotion to natural history reached a pitch which can only be called obsessional. For the rest, he cut himself off from most social contacts, and from almost the whole non-scientific area of human interest -poetry, art, politics and, to a large extent, religion. Or perhaps one should say he was cut off, by a chronic digestive illness against which the only effective remedy seems to have been work, but which often left him too incapacitated even for that. It is Darwin, the pillar of Victorian achievement, rather than Proust, the recorder of Victorian society in decay, who is really the example of the invalid genius, whose intellectual life was passed on a sofa. But for all that, he possessed in full measure another solid Victorian virtue-he was an excellent man of business and managed his investments (largely in railways) so that at his death he left a very sizable fortune.

How did this character-physically tortured, one must suppose, by some psychosomatic trouble, and retaining an unruffled intellectual assurance at the expense of extreme concentration on observing the external world-grow out of the relatively straightforward and energetic young man we meet in the "Voyage of the Beagle", with his enjoyment of a dinner of freshly killed beef grilled at the campfire of the Gauchos on the Argentinian pampas? And what influence, if any, did the peculiar forces which must have been buried in Darwin's odd personality exert on his scientific theories, which, it must not be forgotten, carried with them consequences of the most profound importance for our philosophies both of society and of the individual ? Sir Arthur Keith does not attempt to answer such questions, although he allows himself a few asides which touch on them. But he stage-manages the appearance before us of a historical personage of great magnitude and complexity, whose personality undoubtedly deserves much fuller study and discussion than has yet been given to it.

C. H. WADDINGTON

\section{WEATHER OF THE TROPICS}

\section{Tropical Meteorology}

By Herbert Riehl. Pp. $\mathrm{x}+392$. (London : McGraw. Hill Publishing Company, Ltd., 1954.) 61s.

$T \mathrm{~T}$ is not a little odd that text-books on general 1 meteorology rarely make much reference to tropical meteorology (the hurricane or typhoon may be a notable exception) and even provide rather little in the way of theory which may be usefully applied to the weather and winds of tropical regions. Yet the tropies embrace almost a half of the earth's surface, contain a large number of its people, and have weather which differs notably in style from that of extra-tropical regions. The Second World War, with important theatres of operation in lower latitudes, brought home to many our humiliating ignorance of tropical meteorology and spurred some to a considerable effort of research on the subject. Accepting, for the moment, a purely utilitarian point of view, it is clearly to our interests to further the work then started; for it is within the tropics that solar energy is most freely available-if we can make effective use of it-and, not unrelated, that the most 